\title{
Recycling of Recalcitrant Solid Waste from Herbal Pharmaceutical Industry through Vermicomposting
}

\author{
Veena Das ${ }^{1}$, Sanjeev Satyanarayan ${ }^{2}$, Shanta Satyanarayan ${ }^{3}$ \\ ${ }^{1}$ Assistant, CSIR-NEERI, Nagpur-440020, Maharashtra, India \\ ${ }^{2}$ General Manager, IRG Systems South Asia Pvt. Ltd., New Delhi, India \\ ${ }^{3}$ Ex-Deputy Director, CSIR-NEERI, Nagpur, Maharashtra, India
}

\begin{abstract}
As per the estimates of World Health Organization (WHO) about $80 \%$ of world's population depends on plant and plant products for their primary healthcare. Recently the demand for herbal drugs has increased many folds at the global level, as these herbal medicines do not have any side effects and its cost effectiveness. Huge quantities of solid waste is generated during the production of decoction using roots, stems, nuts, barks, seeds, flowers and fruits. This solid waste is recalcitrant in nature and the dried waste is very sharp and prickly in nature. Hence cannot be used as a fodder, like leguminous plants. At present, this solid waste is simply being disposed off on land. So it was envisaged to try vermicomposting of this solid waste using earthworm species of Eudrilus eugeniae, considering the high content of Volatile Solids of Total Solids to the tune of $81.78 \%$, indicating its good degradable nature. Herbal solid waste depicted $C / N$ ratio of 35.34 and the vermicompost had $\mathrm{C} / \mathrm{N}$ ratio of 12.6. Volatile Solids reduction obtained is around $61.23 \%$ indicating good bioconversion of the waste. $18.6 \%$ moisture content further indicates good quality vermicompost production. Maturity of the compost was confirmed by microbial analysis and also by Scanning Electron Microscopy. Vermicompost prepared out of this herbal pharmaceutical solid waste depicted efficient porosity of $80.489 \%$ and water holding capacity of $87.5534 \%$. Bulk density was around $0.9667 \mathrm{gm} / \mathrm{cm}^{3}$ indicating its suitability for agricultural activity.
\end{abstract}

Keywords- Herbal solid waste, Vermicompost, Eudrilus eugeniae, Microbial analysis, Scanning Electron Microscopy and recalcitrant.

\section{INTRODUCTION}

India being an ancient country having 'Vedic' origin, even today considerable population believes in herbal medicines which is an origin of "Ayurveda". Ayurvedic medicines i.e. herbal medicines manufacturing processes were predominantly in practice in ancient scriptures and literature. Herbal pharmaceuticals and their use are as old as our civilization. WHO has defined the herbal medicines as finished labeled medicinal products that contain as active ingredients of aerial or underground tubers/roots of plants or other plant materials and their combination thereof. Herbal medicines gained popularity due to its easy availability, no side effects and its cost effectiveness. These medicines have stood the test of the time for their safety, efficacy, cultural acceptability and lesser side effects.

Ayurvedic medicines (herbal medicines) are very popular among many Southeast Asian countries. In 1989, World Health Organization adopted a resolution that herbal medicines are of great importance to the health of individual and communities. The global market for herbal drugs is growing rapidly (Technology Report, New Delhi, 2001).

As per the estimates of 2010, herbal medicines market was around US $\$ 62.0$ billion (250,000 crores). The total market of herbal products in India is about one billion dollars.

There are over 7000 licensed herbal medicine manufacturers in India. The process of manufacturing of herbal pharmaceutical medicines involves the cleaning of herbs viz; flowers, roots, stems, leaves, barks, nuts, fruits, seeds, tubers, leaves and resins to remove the dust and soil adhered to the material. A simple schematics of the herbal medicines production and generation of solid and liquid waste is shown in Figure 1. Herbs are dried after cleaning with water and subjected to cutting or powdering through ball mills as per the requirement. A part of the cleaned plant parts are boiled in water for decoction preparation. After decoction preparation solid waste consisting of plant parts is generated as solid waste. This solid waste is very sharp hard and thorny in nature and cannot be used as animal feed, as it is recalcitrant in nature.

Solid Waste generated from these herbal medicine production is enormous in volume and needs proper disposal otherwise may lead to environmental problems. But being plant based production, its ensuing pollution 
problems were not taken very seriously but the awareness has set in recently and steps are being taken to treat the liquid waste generated in this sector (Vanerkar et al, 2005).

One reference has been cited on the treatment of herbal industry solid waste by vermicomposting (Singh et al, 2012).

Vermicomposting is a well known composting technique for stabilizing different degradable organic wastes (Hanc and Vasak, 2015; Wu et al, 2014; Lim et al, 2016).

Literature has cited vermicomposting of hard and very sturdy leaves of coconut tree. Coconut leaves contain high percentage of lignin thus making it very hard, sturdy and they resist decomposition (CPCRI Report, 2009). But this waste was successfully vermicomposted. Normal composting takes longer time for stabilization so now-adays vermicomposting technology is preferred as it accelerates the process and time taken for composting is reduced considerably. Moreover vermicomposting being eco-friendly is based on soil based, beneficial microorganisms e.g. lactic acid, bacteria, yeast, phototrophic bacteria and naturally occurring microorganisms in soil and cattle dung, etc. Hence, the substrate is generally mixed with cattle dung and garden soil and pre-decomposed before vermicomposting.

During vermicomposting earthworms maintain an aerobic condition in the organic substrate, ingest solids and convert them into vermicast. Vermicomposting has an advantage of reducing the total volume and particle size of the biomass waste and side by side increases its relative manurial value. Furthermore, the availability of micro and macro nutrients is generally higher in vermicompost than in the traditional compost and inorganic fertilizers, indicating that vermicompost is a better supplement to stimulate plant growth (Lim et al, 2015b).

Many waste biomasses have been successfully converted by vermicomposting. In early years, water hyacinth a weed was used for vermicomposting. This weed is one of the most productive and hardy of all the weeds and no attempt to control this weed or destroy it by chemical, biological, mechanical or hybrid means have ever achieved total success (Reddy and Smith, 1987; Ramaswamy, 1997; Abbasi et al, 1997).

Combined vermicomposting of crop residues and cattle dung with Eisenia foetida has been reported (Bansal and Kapoor, 2000). A nitrogen deficient pulp and paper industry sludge was vermicomposted by mixing it with nitrogen rich wastes like pig manure, poultry droppings and sewage sludge (Elvira et al, 1997). It is further reported that individually the sludge from pulp and paper industry does not support earthworm growth and activity, but nitrogen rich waste amendment with the waste results in better bioconversion.

Vermicomposting process also depends on the earthworm species utilized. Weed parthenium is very dangerous and creates severe allergy in humans and cannot be treated easily. This weed grows rampantly everywhere and creates health problems. Its disposal poses a great problem. Report on its use in biogas plant has been reported (Banerjee, 1987). But recently, this weed has been vermicomposted using earthworms Eudrilus eugeniae. This is one of the best solutions to get rid of this notorious weed which crept into India from USA. Problem with this weed is that it contains a toxin called parthenin along with phenols. This toxin can be eradicated by vermicomposting technique when mixed with optimum quantity of cow dung. Report further says that around $30-35 \%$ organic carbon and $32-48 \%$ phenol contents are reduced (Rajiv et al, 2013). Vermicompost plays a major role in improving the growth and yield of different agricultural products. Vermicomposting is an appropriate alternative for the safe, hygienic and cost effective disposal of many degradable waste materials. Cellulose rich banana tree peels have been effectively vermicomposted. In addition Eudrilus eugeniae, was used successfully in vermicomposting of various agricultural wastes, such as soybean husk (Lim et al., 2011), rice husk (Lim et al., 2012), rice residues (Shak et al., 2014), empty fruit bunches (Lim et al., 2015a), palm oil mill effluent (Lim et al., 2015b; Lim et al, 2014; Lim and Wu, 2015) and other wastes.

Many animal wastes like pig, cow dung, poultry and even human wastes are reported to have been converted successfully into nutrient rich manure by vermicomposting (Chan et al, 1988; Manuel Aira et al, 2002; Giraddi and Meenatchi, 2008 and Yadav Kunwar, 2010). Thus, disease creating pathogens are also eradicated.

Some special wastes like arcanut and coconut leaves, which are very hard and rich in lignin have been tried for vermicomposting. It is reported that pre-decomposed arcanut and coconut leaves in combination with cattle dung could be efficiently vermicomposted (Chaudappa et al, 1999 and CPCRI report, 2009). It is also found that vermicomposting could be used as an efficient technology to convert empty fruit bunches into nutrient rich organic fertilizers, if the wastes were mixed with cattle dung in an appropriate ratio (Lim et al, 2015a). Guar gum industry waste also had the potential utilization in vermicomposting (Suthar, 2006). Rubber tree leaves, which are very thick and contains sticky latex has also been used for vermicomposting (Chaudhari et al, 2001). 
Another advantage of vermitechnology is the easy and efficient eradication of pathogens and toxic substances present in the substrates. Considering the above factors detailed studies on the vermicomposting of recalcitrant solid waste from herbal pharmaceutical industry was carried out in detail and discussed in this article.

\section{MATERIALS AND METHOD}

Solid waste from a herbal pharmaceutical industry was procured from a well-known local industry - Baidyanath Ayurved Bhavan at Nagpur, Maharashtra. This solid waste was subjected to routine physico chemical analysis and heavy metal analysis as per the standard methods (Clesceri et al, 2012). Results are indicated in Table 1. This recalcitrant solid waste was dried in shade and was cut into smaller pieces and then was used for the experimental work. Cattle dung was brought from a local cattle shed and dried in shade before its use. Physico chemical analysis is shown in Table 23. Garden soil from a nursery was procured for the experimental work.

Earthworm species of Eudrilus eugeniae was obtained from a vermiculture department of Centre of Science for Villages, Wardha, Maharashtra, India.

Herbal industry solid waste, soil and cattle dung were mixed in 1:1:1 ratio and left for predecomposing. Characteristics of this substrate mixture is indicated in Table 3. Predecomposed waste was then transferred into earthenware vermi beds and fifteen number of earthworms were introduced in it. The beds were sprinkled with water and covered with mulch. The beds were kept in shade away from direct sunlight and rain water entry. Daily monitoring was done and moisture content was maintained at the required level. Experiments were carried out in duplicate.

Scanning Electron Microscopy [Model, JEOL, JSM 6380A, USA] was used. Samples were prepared by standard procedure (Bond et al, 1995), where a drop of sterile distilled water on a clean sterile glass coverslip was taken and then a smear was prepared on the coverslip and fixed with the help of flame. After fixing the coverslip was dipped overnight in Millonigs buffer. The cover slip was later removed from the buffer solution and dehydrated in different grades of alcohol. Coverslip was then air dried and cleaned with tissue paper. Finally the samples were ultra sound de-agglomerated in etalon for ten minutes gold splattered and then subjected to SEM analysis.

Few important physical parameters of importance in vermicomposting viz, bulk density, water holding capacity and porosity were also analyzed (Mckenizie et al, 2004). Microbial analysis of vermicompost was also carried out.
An aqueous suspension using vermicompost was prepared as per the method quoted in literature to evaluate the microbial quality of the vermicompost (Pandey et al, 2010). This aqueous suspension was filtered and was subjected to microbial test.

\section{RESULTS AND DISCUSSION}

Herbal Pharmaceutical industry solid waste consists of large size stalks, barks, stems, leaves, nuts, tubers and roots, hence it needs shredding prior subjecting it to vermicomposting. Hence, the waste initially was cut into small size particles. Too fine pieces are not suitable as they get compacted. Cutting into small pieces induces fast vermicomposting, thus vermiconversion time period is reduced.

Compared to other biomasses, this biomass is hard and sharp in nature (Figure 2) and takes little longer time period for vermiconversion. A total of 78 days apart from ten days of predecomposing was required for the complete vermiconversion. Good fluffy granular, dark brown vermicompost with good pleasant earthy smell was obtained on complete vermicomposting. It was analyzed and results are indicated in Table 4.

Original $\mathrm{C} / \mathrm{N}$ ratio of this waste was around 35.34 , while the mixture depicted a $\mathrm{C} / \mathrm{N}$ ratio of 34.17 . Final vermicompost depicted a $\mathrm{C} / \mathrm{N}$ ratio of 12.60 indicating good quality of the vermicompost. $\mathrm{C} / \mathrm{N}$ ratio also indicates the maturity of the compost and its suitability for agricultural use. C:P ratio of vermicoposted substrate was around 20.54 which is well within acceptable limit, but preferable limit quoted in literature is less than 15 (Edwards and Bohlen, 1996). Reaction due to microbial activity during vermicomposting of herbal recalcitrant solid waste resulted in the loss of total organic carbon due to mineralization of organic waste.

Total organic carbon showed decrease in final compost than the initial substrate which was around $39.88 \%$. This reduction is due to the decomposition of the wastes by earthworm activity. The loss of carbon as carbon-dioxide due to microbial respiration and assimilation of simple carbohydrates leads to the reduction in organic carbon. Moreover carbohydrates and other polysaccharides, which are considered to be major source of carbon are digested rapidly by the earthworms.

Organic carbon content of the compost was around $18.9 \%$ which is around $39.88 \%$ less in the final compost which shows good bioconversion, which further confirms that the process of vermicomposting is very efficient. Generally organic carbon content should be more than $17 \%$ in the final vermicompost and in the present study it is more than this standard value (Phirke et al, 2004).

Figure 3 shows the final vermicompost which depicts dark brown colour and fluffy nature. It emitted pleasant 
earthy smell. Earthworm Eudrilus eugeniae is one of the most promising earthworm species used for vermicomposting and Figure 4 indicates healthy earthworm species in the final vermicompost (Sinha et al, 2002; Garg et al, 2006).

Based on its easy availability and efficiency as quoted in literature, this species was chosen for the studies.

$\mathrm{pH}$ of the original raw material / substrate was around 10.57, while the mixture showed a $\mathrm{pH}$ of 8.6 and during vermicomposting it reduced to 7.50 i.e. near neutral. Decrease of $\mathrm{pH}$ in vermicompost might be due to microbial activity during vermiconversion. Production of $\mathrm{CO}_{2}$ and organic volatile acids by microbial aerobic decomposition during the bioconversion is the main reason for the decrease in $\mathrm{pH}$.

Total nitrogen content in the vermicompost increased which is due to the fact that earthworms enhanced the nitrogen cycle. The losses of organic carbon might be responsible for nitrogen addition in the form of mucus, nitrogenous excretory substances, and enzymes from the guts of the earthworm. Mucus, a polysaccharide is secreted by the earthworms to keep the body moist also contributes as enhanced nitrogen fixers and thus nitrogen content increases in the vermicompost (Prakash et al, 2010; Hait et al, 2011).

Original raw material depicted total phosphorus content of $0.32 \%$ while the raw mixture depicted $\mathrm{PO}_{4} \quad 0.62 \%$, which increased to $0.92 \%$ in the final vermicompost. This enhancement of phosphorus content in the final vermicompost is due to mineralization of phosphorus during vermicomposting activity. The release of phosphorus in the plant available form is carried out by microorganisms present in the gut of the earthworms.

Potassium content also showed an increase from the original concentration of $1.23 \%$ in the raw mixture to $16.4 \%$ in the vermicompost. This increase in the potassium content in the vermicompost might be due to fluctuations in the distribution of potassium between nonexchangeable and exchangeable forms. Generally earthworm processed organic material contains high concentration of exchangeable potassium due to enhanced microbial activity during the vermiconversion process which consequently enhances the rate of mineralization (Suthar, 2007).

Increase in Electrical Conductivity was observed and was relatively higher in the final vermicast than initial substrate. It is due to the increase in soluble salt levels like phosphate, ammonium potassium etc. resulting from the mineralization action carried out by earthworms and microorganisms present in the guts of earthworms and also the microorganisms present in the original organic substrate. Reduction in organic carbon from the raw substrate may also be a reason for the increase in Electrical Conductivity.

Percent volatile solids reduction observed is around $61.23 \%$ indicating good / efficient conversion of the substrate by the earthworms. Percent Ash content showed an increase to the tune of $63.41 \%$. This value is well within the literature reported values. Ash contents indicate the organic matter mineralization and efficient waste stabilization.

Important physical parameters of vermicompost are depicted in Table 5. Bulk density is around 0.9667 $\mathrm{gm} / \mathrm{cm}^{3}$ indicating good texture of the compost which would enable smooth root penetration into the soil. Moreover, porosity and water holding capacity also were very congineal for good growth of plants and were $80.487 \%$ and $87.5534 \%$ respectively. Moisture content of the vermicompost was around $18.6 \%$ i.e. well within suitable range.

Important heavy metals present showed increase in concentration and were well within limits.

Vermicompost quality and maturity was studied through Scanning Electron Microscopy and microbial analysis. Scanning Electron Microscope (SEM) photograph Figure 5 shows the raw herbal pharmaceutical solid waste. It can be seen that the cellulosic fibres are devoid of lignin and looks sturdy and hard. SEM of raw material shows presence of bacillus and cocci. It also shows cellulosic fibres in cluster while it is clear from SEM photograph Figure 6 of the vermicompost that the cellulosic fibres have disintegrated completely by the microbial activity. Hydrolysis has taken place due to the presence of yeast cells and acidophilic bacteria, once the sugar and acid formation takes place during fermentation of cellulosic raw material.

Raw material was light dirty green to brown in colour but after vermicomposting depicted dark brown colour with fluffy nature.

Final vermicompost depicted pleasant earthy smell indicating complete bioconversion of the raw substrate.

SEM of vermicomposted herbal waste shows beautiful uniform matrix giving a fibrous look and indicates good conversion.

Earthworm's foregut acts as a mechanical blender and modifies the physical structure of the ingested raw material and consequently increases the surface area of the substrate after digestion. Increased surface area helps the digestive enzymes to have more contact with the substrate particles for action. In the earthworm, gut associated microbes provide several essential enzymes to digest the ingested organic waste material. This activity has been efficiently carried out, is seen in the SEM of vermicompost. 
Microbial analysis of the liquid suspension of vermicompost as shown in Table 6 indicated no pathogenic bacteria and no fungal cells. Presence of Actinomycetes population also shows good microbial activity during vermiconversion.

\section{CONCLUSION}

It can be inferred that herbal pharmaceutical solid waste is a good substrate with high percentage of volatile solids of total solids indicating its degradable nature. It can hence be easily vermicomposted. Vermicompost produced has a good granular texture with efficient percentage of water holding capacity and porosity. Vermicompost had pleasant earthy smell.

$\mathrm{C} / \mathrm{N}$ ratio reduced and was around 12.6 indicating efficient earthworm's bioconversion of the waste. Manurial value of the vermicompost in terms of NPK was rich. Scanning Electron Microphotograph confirmed the complete disintegration of cellulosic fibres by efficient working of earthworms and microbial activity.

Finally it can be inferred that recalcitrant herbal pharmaceutical solid waste can be disposed off easily with recovery of value added product by vermitechnology.

Table.1: Characteristics of Raw Recalcitrant Solid Waste of Herbal Pharmaceutical Industry

\begin{tabular}{|l|l|}
\hline Parameters & Values \\
\hline $\mathrm{pH}$ & 10.57 \\
\hline Conductivity $\left(\mu \mathrm{s} / \mathrm{cm}^{2}\right)$ & 868 \\
\hline Alkalinity as $\mathrm{CaCO}_{3}$ & 900 \\
\hline Chloride as $\mathrm{Cl}$ & 22.6 \\
\hline Sodium as Na & 11.8 \\
\hline Potassium as $\mathrm{K}$ & 0.9 \\
\hline Nitrogen as $\mathrm{N}$ & 1.20 \\
\hline Sulphate as $\mathrm{SO}_{4}$ & 121.2 \\
\hline Phosphate as $\mathrm{PO}_{4}$ & 0.32 \\
\hline$\%$ Organic Carbon & 42.40 \\
\hline$\%$ Total Solids & 89.4 \\
\hline \% Total Volatile Solids & 73.12 \\
\hline$\%$ Ash content & 18.21 \\
\hline$\%$ Volatile Solids of Total Solids & 81.78 \\
\hline \% Moisture & 10.6 \\
\hline C/N Ratio & 35.34 \\
\hline Heavy Metals (in mg/l) & \\
\hline Cadmium & 0.0050 \\
\hline Cobalt & 0.0264 \\
\hline Chromium & 0.1070 \\
\hline Copper & 0.8645 \\
\hline Iron & 56.3826 \\
\hline Manganese & 2.4063 \\
\hline Nickel & 0.0686 \\
\hline & \\
\hline & \\
\hline
\end{tabular}

\begin{tabular}{|l|l|}
\hline Lead & 0.0825 \\
\hline Zinc & 3.2259 \\
\hline
\end{tabular}

Table.2: Characteristics of shade dried cattle dung

\begin{tabular}{|l|l|}
\hline Parameters & Values \\
\hline $\mathrm{pH}$ & 7.5 \\
\hline Conductivity $\left(\mu \mathrm{s} / \mathrm{cm}^{2}\right)$ & 2200 \\
\hline Alkalinity as $\mathrm{CaCO}_{3}$ & 4382 \\
\hline Chloride as $\mathrm{Cl}$ & 236 \\
\hline Sodium as $\mathrm{Na}$ & 5.2 \\
\hline Potassium as $\mathrm{K}$ & 0.29 \\
\hline Nitrogen as $\mathrm{N}$ & 0.92 \\
\hline Sulphate as $\mathrm{SO}_{4}$ & 16.20 \\
\hline Phosphate as $\mathrm{PO}_{4}$ & 0.63 \\
\hline$\%$ Total Organic Carbon & 39.35 \\
\hline$\%$ Total Solids & 93.0 \\
\hline$\%$ Total Volatile Solids & 67.85 \\
\hline$\%$ Ash content & 27.04 \\
\hline $\begin{array}{l}\text { Volatile Solids of Total } \\
\text { Solids }\end{array}$ & 72.96 \\
\hline$\%$ Moisture & 7.0 \\
\hline C/N Ratio & 42.77 \\
\hline Heavy Metals (in mg/l) & \\
\hline Cadmium & 1.28 \\
\hline Cobalt & 0.032 \\
\hline Chromium & 18.00 \\
\hline Copper & 35.35 \\
\hline Iron & 1284 \\
\hline Manganese & 116 \\
\hline Nickel & 0.005 \\
\hline Lead & 2.2 \\
\hline Zinc & 141.6 \\
\hline
\end{tabular}

Table.3: Characteristics of Raw Substrate Mixture

\begin{tabular}{|l|l|}
\hline Parameters & Values \\
\hline $\mathrm{pH}$ & 8.6 \\
\hline Conductivity $\left(\mu \mathrm{s} / \mathrm{cm}^{2}\right)$ & 948 \\
\hline Alkalinity as $\mathrm{CaCO}_{3}$ & 390 \\
\hline Chloride as $\mathrm{Cl}$ & 32 \\
\hline Sodium as $\mathrm{Na}$ & 24.6 \\
\hline Potassium as $\mathrm{K}$ & 1.23 \\
\hline Nitrogen as $\mathrm{N}$ & 0.92 \\
\hline Sulphate as $\mathrm{SO}_{4}$ & 74 \\
\hline Phosphate as $\mathrm{PO}_{4}$ & 0.62 \\
\hline$\%$ Organic Carbon & 31.44 \\
\hline$\%$ Total Solids & 85.6 \\
\hline$\%$ Total Volatile Solids & 54.2 \\
\hline$\%$ Ash content & 36.68 \\
\hline $\begin{array}{l}\text { \% Volatile Solids of Total } \\
\text { Solids }\end{array}$ & 63.3 \\
\hline \% Moisture & 14.4 \\
\hline
\end{tabular}




\begin{tabular}{|l|l|}
\hline C/N Ratio & 34.17 \\
\hline Heavy Metals (in mg/l) & \\
\hline Cadmium & 0.092 \\
\hline Cobalt & 0.0012 \\
\hline Chromium & 8.126 \\
\hline Copper & 0.7212 \\
\hline Iron & 88.62 \\
\hline Manganese & 3.200 \\
\hline Nickel & 0.0910 \\
\hline Lead & 0.0032 \\
\hline Zinc & 60.806 \\
\hline
\end{tabular}

\begin{tabular}{|l|l|}
\hline Cadmium & --ND-- \\
\hline Cobalt & - ND-- \\
\hline Chromium & 0.1272 \\
\hline Copper & 0.9428 \\
\hline Iron & 202.66 \\
\hline Manganese & 5.7820 \\
\hline Nickel & 0.1120 \\
\hline Lead & 0.0191 \\
\hline Zinc & 0.8817 \\
\hline
\end{tabular}

$\%$ Volatile Solids Reduction $=\mathbf{6 1 . 2 3}$

Table.4: Characteristics of Vermicompost Baidyanath Recalcitrant

\begin{tabular}{|l|l|}
\hline Parameters & Values \\
\hline $\mathrm{pH}$ & 7.50 \\
\hline Conductivity $\left(\mathrm{ms}^{\prime} \mathrm{cm}^{2}\right)$ & 1.162 \\
\hline Alkalinity as $\mathrm{CaCO}_{3}$ & 140 \\
\hline Chloride as $\mathrm{Cl}$ & 49.852 \\
\hline Sodium as Na & 19.4 \\
\hline Potassium as K & 16.4 \\
\hline Nitrogen as $\mathrm{N}$ & 1.50 \\
\hline Sulphate as $\mathrm{SO}_{4}$ & 5.15 \\
\hline Phosphate as $\mathrm{PO}_{4}$ & 0.92 \\
\hline$\%$ Organic Carbon & 18.9 \\
\hline \% Total Solids & 81.4 \\
\hline \% Total Volatile Solids & 32.6 \\
\hline \% Ash content & 59.94 \\
\hline$\%$ Volatile Solids of Total Solids & 40.06 \\
\hline \% Moisture & 18.6 \\
\hline C/N Ratio & 12.60 \\
\hline Heavy Metals (in mg/l) & \\
\hline
\end{tabular}

Table.5: Physical parameters of vermicompost and soil

\begin{tabular}{|l|c|c|}
\hline \multirow{2}{*}{ Parameters } & \multicolumn{2}{|c|}{ Sample } \\
\cline { 2 - 3 } & Soil & Compost \\
\hline Bulk density (in g/cm ${ }^{3}$ ) & 1.6966 & 0.9667 \\
\hline Porosity (in \%) & 46.8815 & 80.4890 \\
\hline $\begin{array}{l}\text { Water Holding Capacity (in } \\
\%)\end{array}$ & 38.7447 & 87.5534 \\
\hline
\end{tabular}

Table.6: Microbial Quality of the vermicompost

\begin{tabular}{|c|l|l|}
\hline S. No. & \multicolumn{1}{|c|}{ Microbes } & c.f.u/ml \\
\hline 1. & Total count of bacteria & $0.01 \times 10^{8}$ \\
\hline 2. & Total count of fungi & Nil \\
\hline 3. & Total Actinomycetes & $0.01 \times 10^{7}$ \\
\hline
\end{tabular}

* No Pathogenic bacteria found. 


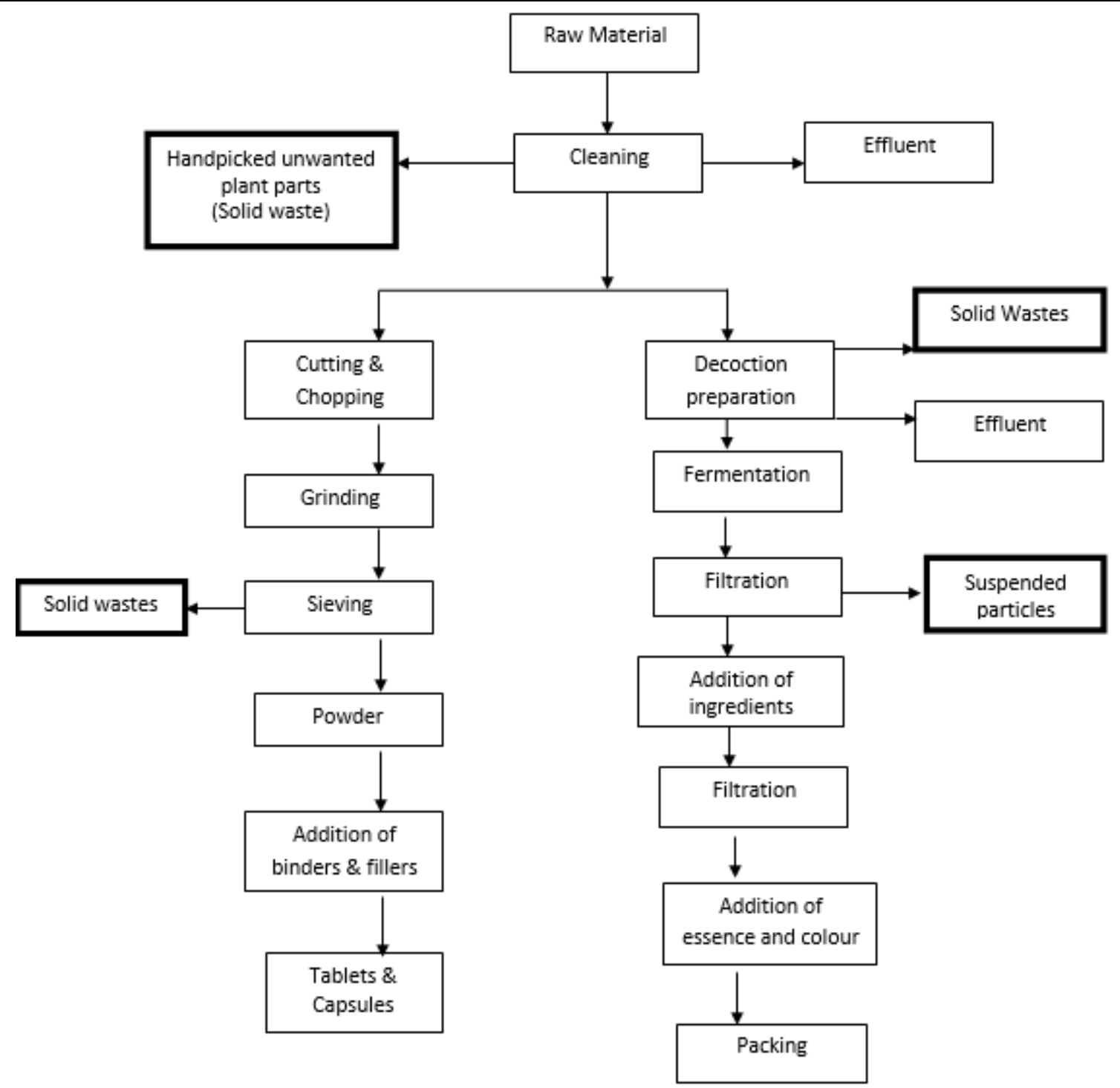

Fig.1: Schematics of Decoction extraction, preparation of capsules and solid waste generation sources

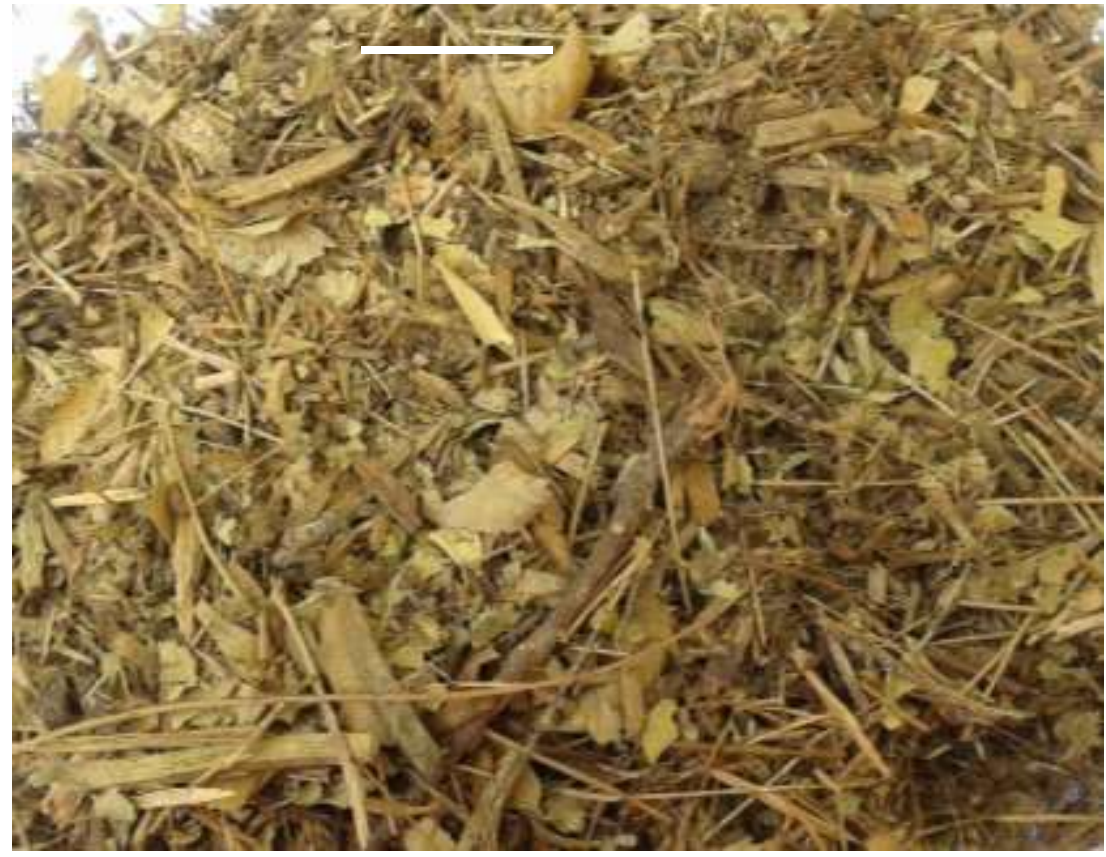

Fig.2: Raw Solid Waste from Herbal Pharmaceutical Industry 


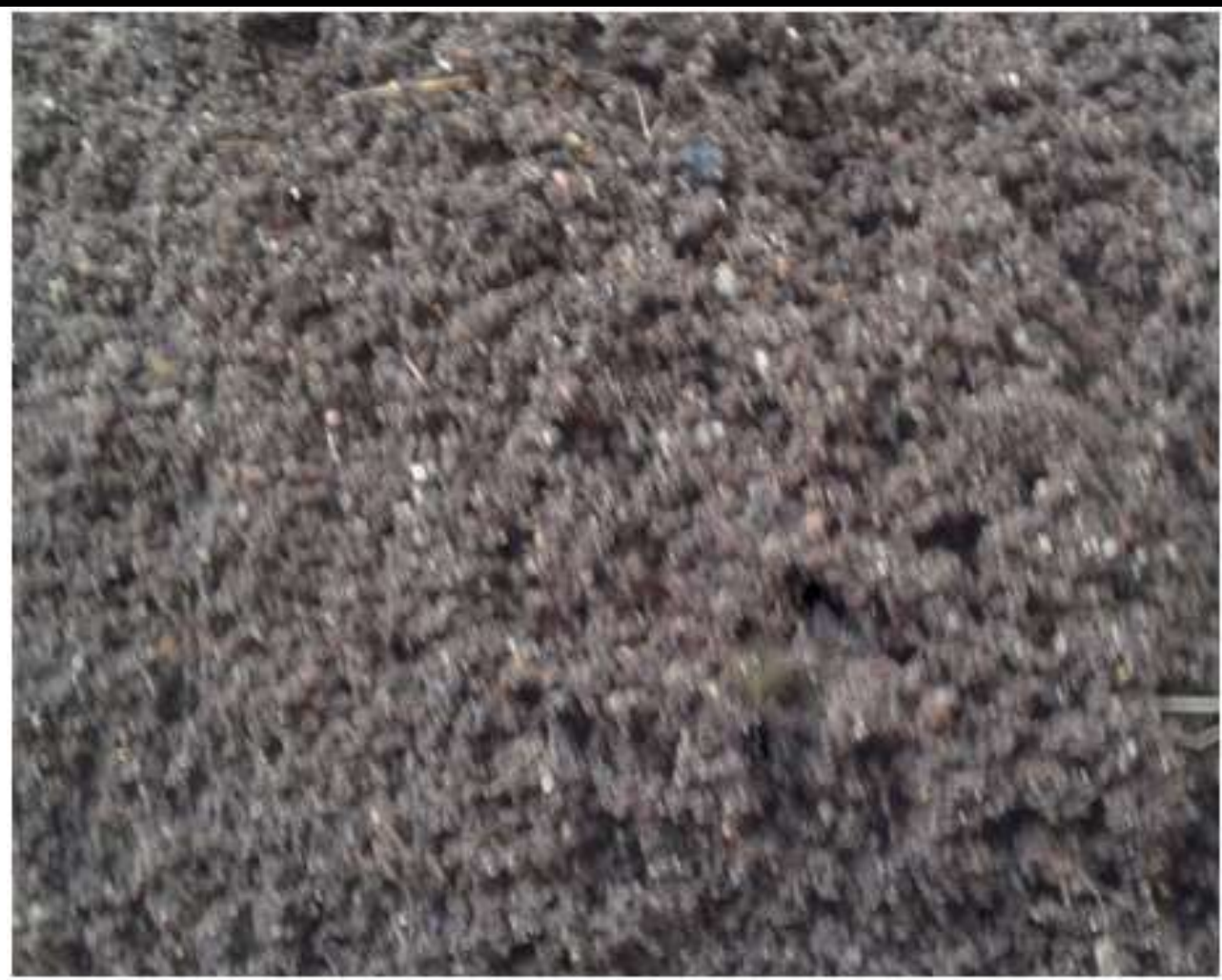

Fig.3: Vermicompost prepared using Herbal Pharmaceutical Solid Waste

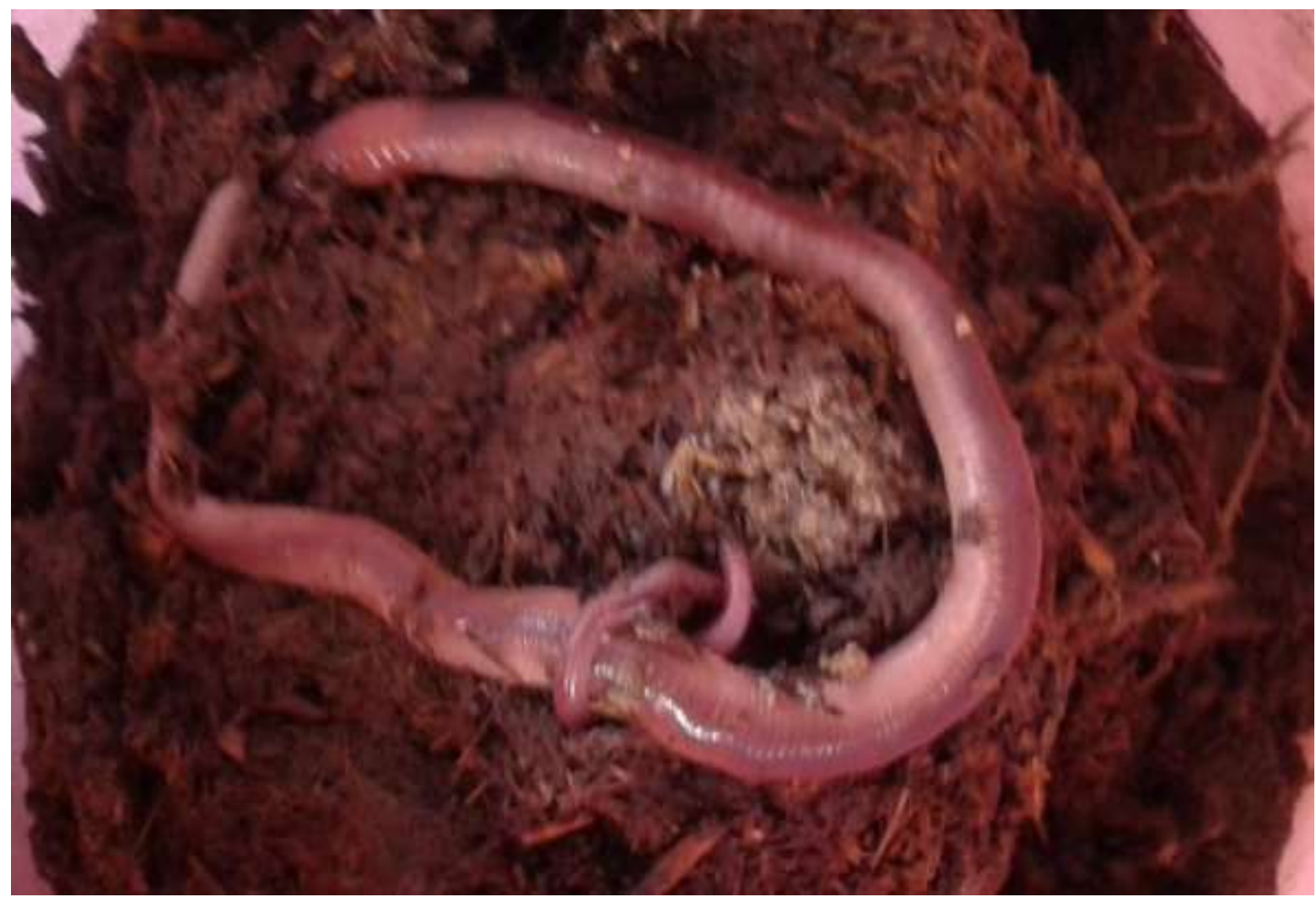

Fig.4: Healthy Earthworm species of Eudrilus Euginiae 


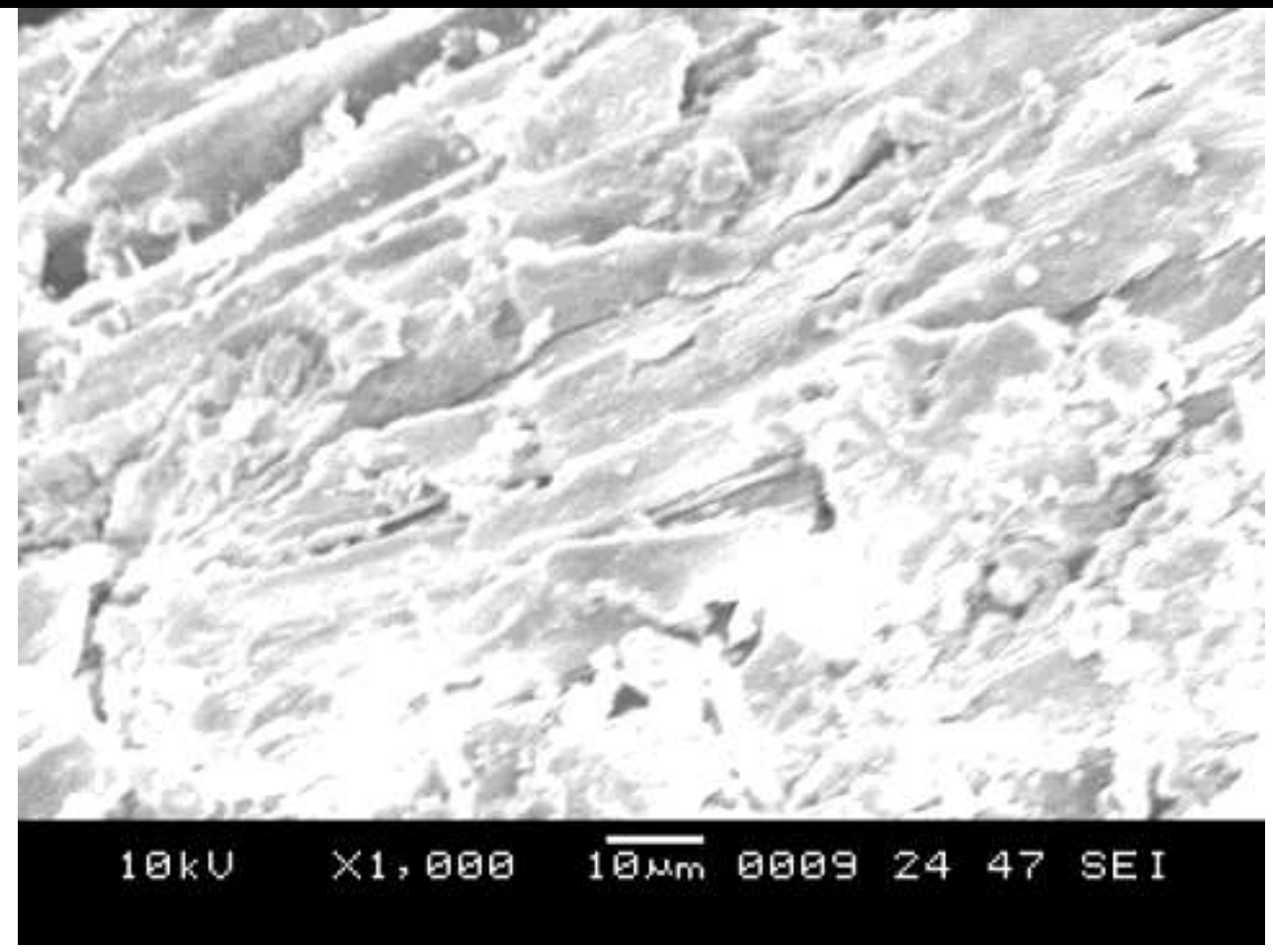

Fig.5: SEM of raw herbal pharmaceutical industry solid waste

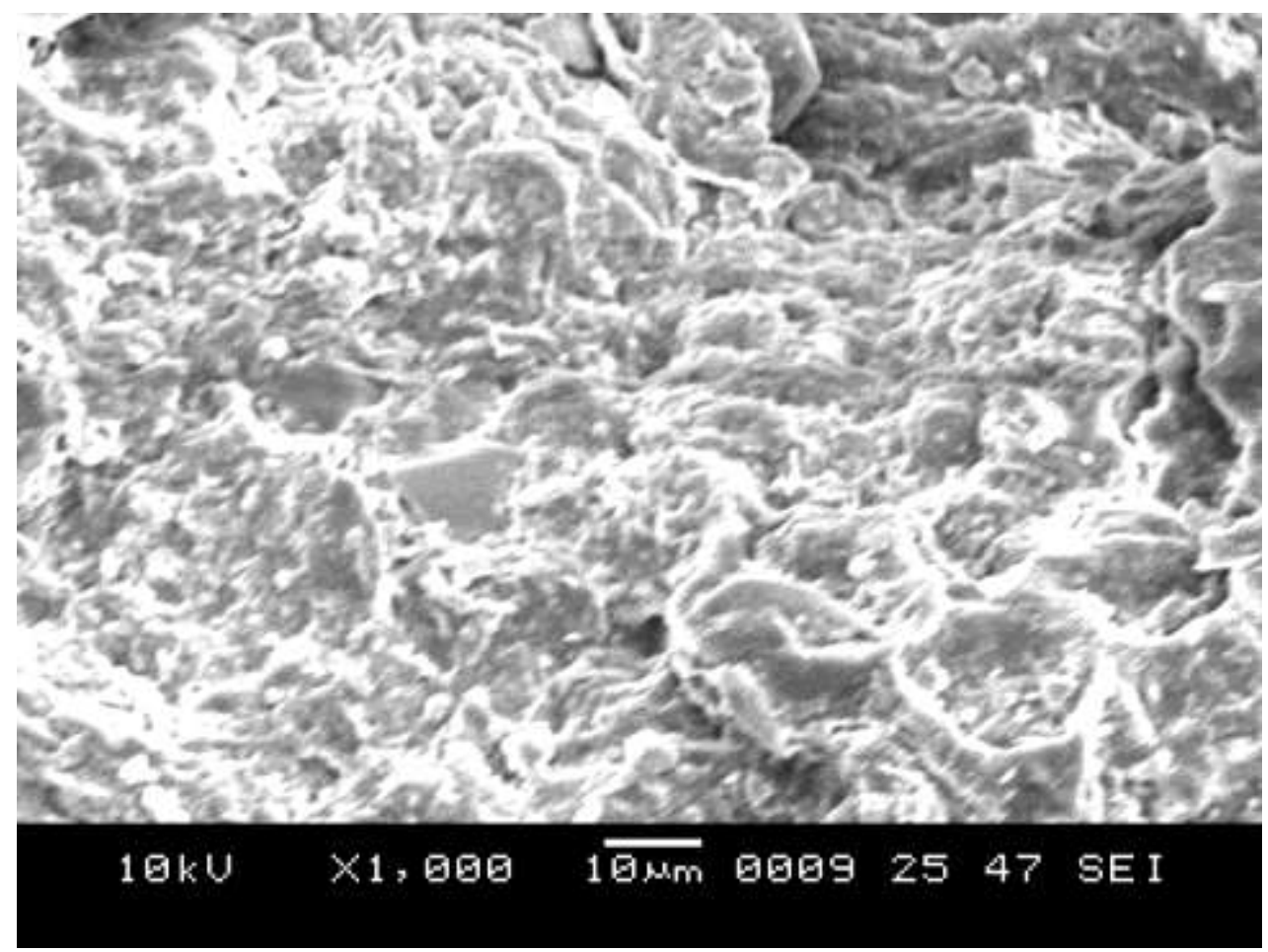

Fig.6: SEM of vermicomposted solid waste from herbal pharmaceutical industry

\section{REFERENCES}

[1] Abbasi, S. A., Abbasi, N. and Bhatia, K. K. S., 1997. In: Wetlands of India: Ecology and Threats. Vol. III. Discovery Publishing House, New Delhi.

[2] Banerjee, A. K., 1987. Biogas from Parthenium. Article published in Times of India, India.

[3] Bansal, S. and Kapoor, K. K., 2000.
Vermicomposting of crop residues and cattle dung with Eisenia foetida. Bioresearch Technology, 73: pp 95 - 98.

[4] Bond, A. J., Fan, F. R. and Mirkin, M., 1995. Scanning Electron Microscopy in Physical Electrochemical Microscopy, Principles, Methods and Applications. Marcel Dekker, New York. 
[5] Chan, P. L. S. and Griffiths, D. A., 1988. The vermicomposting of pre-treated pig manure. Biological Wastes, 24: pp 57 - 69.

[6] Chaudappa, P., Biddappa, C. C. and Sujata, S., 1999. Effective recylcing of organic waste in arcanut (Arca catechu L.) and cocoa (Theombrome cocoa L.) plantation through vermicomposting. Indian Journal of Agricultural Science, 69: pp 563 - 566.

[7] Chaudhari, P. S. and Pal, T. K., Bhattacharjee, G. and Dey, S. K., 2001. Suitability of rubber leaf litter (Hevea brasiliensis var. PRIM 600) as substrate for epigeic earthworms, Perionyx excavatus, Eudrilus eugeniae and Eisenia foetida. Proceedings of VII Nat. Symp. Soil Biol. Ecol., G. K. V. K., Bangalore, 7-9, Nov.: pp 18 - 26.

[8] Clesceri, L. S., Franson, M. A. H., Eataon, A. D., Greenberg, A. E., 2012. Standard Methods for the examination of Water and Wastewater. $22^{\text {nd }}$ Edition, 2012. APHA, AWWA and WPCF, Washington D. C., U.S.A.

[9] CPCRI Report, 2009. Coconut leaf vermicompost and vermiwash, Kasargod, Kerala.

[10] Edwards, C. A. and Bohlen, P. J., 1996. Biology and Ecology of earthworms. 3rd edition, chapman and Hall, New York / London.

[11] Elvira, C., Sampedro, L., Dominguez, J. and Mato, S., 1997. Vermicomposting of wastewater sludge from paper pulp industry with nitrogen rich materials. Soil Biol. Biochem., Vol. 29, No. 3/4: pp $759-762$.

[12] Garg, V. K., Chand, S., Chhiller, A., Yadav, Y. K., 2006. Growth and reproduction of Eisenia foetida in various animal wastes during vermicomposting. Applied Ecol. And Environ. Res. 3: pp 51 - 59.

[13] Girradi, R. S. and Meenatchi, R., 2008. Recycling of sheep and poultry manure using earthworm, (Kinberg). Karnataka Journal Agri. Sci., 21: pp 583 585.

[14] Hait, S. and Tare, V., 2011. Vermistabilization of primary sewage sludge. Bioresource Technology 102: pp 2812 - 2820.

[15] Hanc, A. and Vasak, F., 2015. Processing separated digestate by vermicomposting technology using earthworms of the genus Eisenia. International Journal of Environmental Science and Technology, 12(4): pp $1183-1190$.

[16] Lim, P. N., Wu, T. Y., Clarke, C. and Daud, N. N. N., 2015a. A potential bioconversion of empty fruit bunches into organic fertilizer using Eudrilus eugeniae. International Journal of Environmental Science and Technology, 12(8): pp 2533 - 2544

[17] Lim, P. N., Wu, T. Y., Sim, E. Y. S. and Lim, S. L., 2011. The potential reuse of soybean husk as feedstock of Eudrilus eugeniae in vermicomposting. Journal of the Science of Food and Agriculture, 91(14): pp 2637 - 2642.

[18] Lim, S. L. and Wu, T. Y., 2015. Determination of maturity in the vermicompost produced from palm oil mill effluent using spectroscopy, structural characterization and thermogravimetric analysis. Ecological Engineering, 84: pp 515 - 519.

[19] Lim, S. L., Lee, L. H. and Wu, T. Y., 2016. Sustainability of using composting and vermicomposting technologies for organic solid waste biotransformation: Recent overview, greenhouse gases emissions and economic analysis. Journal of Cleaner Production, 111: pp 262 - 278.

[20] Lim, S. L., Wu, T. Y. and Clarke, C., 2014. Treatment and biotransformation of highly polluted agro-industrial wastewater from a palm oil mill into vermicompost using earthworms. Journal of Agricultural and Food Chemistry, 62(3): pp 691 698.

[21] Lim, S. L., Wu, T. Y., Lim, P. N. and Shak, K. P. Y., 2015b. The use of vermicompost in organic farming: Overview, effects on soil and economics. Journal of the Science of Food and Agriculture, 95(6): pp 1143 - 1156.

[22] Lim, S. L., Wu, T. Y., Sim, E. Y. S. and Clarke, C., 2012. Biotransformation of rice husk into organic fertilizer through vermicomposting. Ecological Engineering, 41: pp 60-64.

[23] Manuel, A., Fernando Monroy, Dominguez, J. and Mato, S., 2002. How earthworm density affects microbial biomass and activity in pig manure. European Journal of Soil Biology, 38: pp 7 - 10.

[24] Mckenizie, N. J., Jacquier, D. J., Isbell, R. F., Brown, K. L., 2004. Australian soils and landscapes. An illustrated compendium. CSIRO Publishing, Collingwood, Victoria.

[25] Pandey, R. and Kalra, A., 2010. Inhibitory effects of vermicompost produced from agro waste of medicinal and aromatic plants on egg hatching in Meloidogyne incognito (Kofoid \& White) Chitwood. Current Science Vol. 98. No. 6: pp 833 835.

[26] Phirke, N., Mishra, S. and Joshi, P., 2004. Quality control of biomanures. In: Manual of production and quality assurance of bioinoculants, biomanures and biopesticides. KVIC - IIT, Delhi project.

[27] Prakash, M. and Karmegam, N., 2010. Dynamics of nutrients and microflora during vermicomposting of mango leaf litter (Mangifera indica) using Perionyx ceylanensis. Int. J. of Global Environ. 10: pp 339 353.

[28] Rajiv, P., Rajeshwari, S., Yadav, H., and R. 
Rajendran V., 2013. Vermiremediation:

Detoxification of parthenin toxin from parthenium weed. http/link springer.com

[29] Ramaswamy, E. V., 1997. Biowaste treatment anaerobic reactors. Ph. D. Thesis, Pondicherry University, Pondicherry, India.

[30] Reddy, K. R. and Smith, W. H., 1987. In: Aquatic plants for water treatment and resource recovery. Magnolia Publishing, Organization, New Delhi: pp 15 - 19.

[31] Shak, K. P. Y., Wu, T. Y., Lim, S. L. and Lee, C. A., 2014. Sustainable reuse of rice residues as feedstocks in vermicomposting for organic fertilizer production. Environmental Science and Pollution Research, 21(2): pp 1349 - 1359.

[32] Singh, D. and Suthar, S., 2012. Vermicomposting of herbal pharmaceutical industry solid wastes. Ecological Engineering 39: pp 1 - 6.

[33] Sinha, R. K., Heart, S., Aggarwal, S., Asadi, R. and Corretero, E., 2002 Vermiculture and waste management study of action of earthworms Eisenia foetida, Eudrilus eugeniae and Perionyx excavatus on biodegradation of sane community waste in India and Australia. Environmentalist, 22: pp 264 - 268.

[34] Suthar, S., 2006. Potential utilization of Guar Gum Industrial waste in vermicompost production. Bioresource Technology, 97: pp 2472 - 2477.

[35] Suthar, S., 2007. Nutrient changes and biodynamics of epigeic earthworm Perionyx excavatus during recycling of some agricultural wastes. Biores. Technology 1(4): pp 315-320.

[36] Vanerkar, A. P. and Satyanarayan, S., 2005. Herbal Pharmaceutical wastewater treatment by conventional coagulants and synthetic polyelectrolytes. Poll. Res. 24(2): pp 341 - 346.

[37] Wu, T. Y., Lim, S. L., Lim, P. N. and Shak, K. P. Y., 2014. Bio-transformation of biodegradable solid wastes into organic fertilizers using composting or / and vermicomposting. Chemical Engineering Transactions, 39: pp 1579 - 1584.

[38] Yadav Kunwar D., Tare V. and Mansoor Ahammed, 2010. Vermicomposting of source separated human faeces for nutrient recycling. Waste Management 30: pp 50-56. 